\title{
GENETICS AND IMMUNOLOGY
}

F. M. BURNET and FRANK FENNER

Walter and Eliza Hall Institute of Medical Research, Melbourne, Australia

\section{INTRODUCTION}

Received 6.iii.48

IN recent years as part of the universal process by which every science averlaps sooner or later the field of every other science, genetics and immunology have been finding many points of mutual interest. Immunology has developed as a predominantly " applied" science with a constant reference to the immediate problems of human disease and its treatment, and it is still largely unassimilated into general biology. In fact it is characteristic of the history of immunology that the present interest of immunologists in genetic matters stems mainly from the discovery of the $R h$ group of blood cell antigens with their very important practical implications in obstetrics.

Attempts to bring the facts and concepts of immunology into more effective and satisfying contact with the other biological sciences have been more frequent in recent years. Landsteiner's influence has been outstanding, and his ideas as developed by Marrack, Heidelberger, Pauling and others have given a strong bias toward the interpretation of immunological phenomena in almost exclusively chemical terms. This attitude has been of the greatest value in bringing a more accurately quantitative technique into immunological investigation and a more precise terminology to its discussion. Nevertheless it must still be maintained that the phenomena of immunity are biological phenomena and are no more expressible simply in chemical terms than those of growth, bodily repair, or reproduction.

Our object is primarily to describe the immunological techniques which have been applied to genetic investigations and to discuss the significance of immunological findings. In our view it is impossible to do this without some discussion of the nature of antibodies and the mode of their production. Some space is therefore given to an attempt to interpret the basic immunological phenomena in terms of modern biological conceptions.

We may first give a brief account of the fields in which genetics and immunology overlap. These are :-

(I) The differentiation of bodily components in different individuals of the same species (or of related species) by serological methods, and the use of these differences as markers in genetic experiments or 
observations. The first and most important example is the division of human individuals into four major "blood groups" in terms of antigens present on the surface of their red blood cells. All the other investigations of red cell antigens in human beings and in other animals and birds are essentially similar in character.

(2) The impossibility in mammals and birds of transplanting tissue from one individual to another has been shown to be due essentially to the development of immunological responses which prevent the graft's survival. A limited degree of genetic experimentation has been carried out in regard to this phenomenon.

(3) Antibody production, the basic phenomenon on which all immunological investigation rests, has been ascribed to the existence and modification of self-replicating units within the antibody-producing cells with the associated possibility of the passage of antibody-producing power from a cell to its descendant cells (Burnet, I94 I). If this conception is established it brings the antibody-producing mechanism into line with the growing number of cytoplasmic entities which have demonstrably, or probably, power of self-replication in response to environmental rather than nuclear stimuli. The nature of the relation between genes and these cytoplasmic entities is a matter of the first importance to genetic theory.

(4) There are genetically determined differences between individual human beings which are in part responsible for the presence or absence of allergic disease. Allergic disease may be defined with reasonable exactitude as disease resulting from inappropriate functioning of immunological mechanisms within the body. Here and there, also, one finds evidence of the existence of strains of laboratory animals which have unusually high, or unusually low, efficiency in producing some type of immune response.

Each of these fields will be discussed, some at greater length than others. Both the authors are immunologists with limited knowledge and no actual experience of genetic work. They can attempt no more than to make available to geneticists information and ideas derived from one science that may serve as a stimulus to advance in another.

\section{OUTLINE OF IMMUNOLOGICAL METHODS APPLIED IN GENETIC WORK}

The following is a brief resumé of current teaching in regard to the basic immunological concepts of antigen, antibody and immunologically altered cell activity.

An antigen is a molecular species, either free or incorporated in the substance of an organism, which when introduced parenterally into a suitable mammalian host (in laboratory practice almost always the rabbit) gives rise to a specific change in the host which may be either the development of antibody in the blood or tissue fluids, or the development of some form of specific tissue reactivity. 
Antibody as normally observed consists of molecules of serum globulin which differ from other such molecules in combining readily with the corresponding antigen (or with other substances which have sufficient similarity in chemical structure) but not with unrelated substances. The same aspects of the molecular structure of the antigen (antigenic determinants) as are concerned with antibody reactions in vitro are concerned with provoking the reaction (often histamine liberation) of sensitised cells.

The normal type of antigen-antibody reaction observed in immunological work is an aggregation reaction in the test tube. If a soluble antigen is used, mixture in appropriate concentration with immune serum results in the formation of a visible precipitate. Current theory regards both antigen and antibody molecules as "multivalent," i.e. capable of combining simultaneously with more than one of the complementary molecules. The precipitate appears as a result of the development of a "lattice" of reacting antigen and antibody molecules.

Where cellular antigens are used the aggregation reaction takes the form of agglutination, the antibody molecules functioning as bridges to hold the cells together. On occasion anti-red cell sera are titrated by hæmolytic methods, fresh guinea-pig serum (complement) being included in the system to induce hæmolysis of those cells to which antibody has been adsorbed. The antibody recognised by means of a precipitation reaction is called a precipitin, that recognised by means of an agglutination reaction is known as an agglutinin, and when hæmolytic methods are used for titration the antibody is called a hamolysin. By varying the type of experiment the same antibody molecules may cause precipitation, agglutination, or hæmolysis.

If very low concentrations of antigen only are available, complement fixation methods may be used. These depend on the fact that antigenantibody complexes too small to produce macroscopic precipitation will actively adsorb complement which is thereby rendered unavailable for the indicator reaction (hæmolysis of sensitised red cells).

Sensitisation reactions have been little used in immuno-genetic studies, but brief reference to them will be made in a later section. The commonest method of demonstrating acquired tissue reactivity is to inoculate the antigen intradermally in the sensitised animal. An erythematous reaction with variable degrees of swelling results. The reaction is not observed in normal animals similarly injected. Other methods involve demonstration of the anaphylactic state in guinea-pigs by either $(a)$ injecting the antigen intravenously with production of characteristic symptoms and death, or $(b)$ by in vitro tests on the contractility of gut or uterine preparations from sensitive animals using the Schultz-Dale technique. A special type of immunologically modified tissue response is seen in experiments involving transfer of living cells by grafting from one animal to another (see section 4).

In genetic work it is common to inject suitable antibody-producers, 
usually a series of rabbits, with blood cells from a group of individual animals whose genetic interrelations are being studied. Each sample of cells is inoculated in suitable doses over a certain period of time, into two or more rabbits. Serum samples are obtained about two weeks after the last immunising dose. The immune serum will in general be found to agglutinate red cells of the type used for immunisation to high titre, but it will also agglutinate, often to the same titre, cells from related species of subspecific groups. Since genetic studies can only be concerned with differences it is desirable to eliminate from the serum all antibody which is common to the two composite antigens used. The procedure used is derived from the analogous bacteriological technique and consists in cross absorption. If two individuals, $\mathrm{X}$ and $\mathrm{Y}$, are being examined for serological differences in their red blood cells, anti-X and anti-Y sera are prepared in rabbits. Anti-X serum is absorbed with $Y$ cells and anti-Y serum with $\mathrm{X}$ cells. Samples of the absorbed sera are then tested with both $\mathrm{X}$ and $\mathrm{Y}$ cells ; a sharp difference of the type shown in the table will be evident, provided there are real antigenic differences between $\mathrm{X}$ and $\mathrm{Y}$ types of cell.

TABLE

Cross absorption of anti-red cell sera

\begin{tabular}{|c|c|c|c|c|}
\hline \multirow{2}{*}{\multicolumn{2}{|c|}{ Serum }} & \multirow[b]{2}{*}{ Absorbed with } & \multicolumn{2}{|c|}{ Titre against } \\
\hline & & & $\mathrm{X}$ cells & $Y$ cells \\
\hline Anti-X & & $\begin{array}{l}\bar{X} \\
Y\end{array}$ & $\begin{array}{r}20,000 \\
<100 \\
8,000\end{array}$ & $\begin{array}{r}10,000 \\
<100 \\
<100\end{array}$ \\
\hline Anti-Y & · & $\begin{array}{l}\bar{X} \\
Y\end{array}$ & $\begin{array}{r}20,000 \\
<100 \\
<100\end{array}$ & $\begin{array}{r}20,000 \\
10,000 \\
<100\end{array}$ \\
\hline
\end{tabular}

In general the homologous antigen will absorb all antibody out of an antiserum; any heterologous antigen will leave behind at least some of the antibody reacting with the homologous antigen. There are probably two different reasons for this behaviour when the complex antigens such as blood cells are used. In the first place several distinct antigenic molecular species may be involved. One type of cell may be formulated as containing antigens $A, B, C$ and D, the other $\mathrm{A}, \mathrm{B}, \mathrm{E}$ and $\mathrm{F}$; the antisera will contain corresponding antibodies $a, b, c, d$ and $a, b, e, f$. Cross absorption will give sera containing antibodies $c, d$ and $e, f$ respectively. It has, however, been shown in several instances that the population of antibody molecules which is produced by a single antigen $A$ is not uniform, but contains a proportion of antibody which can be differentiated by its behaviour on absorption with related antigens $\mathrm{A}^{\prime} \mathrm{A}^{\prime \prime}$, etc. (Landsteiner and 
van der Scheer, I936 ; Burnet, 1934). This second type of difference between antigens is particularly to be suspected when close quantitative control of absorbing doses is necessary to obtain specific serological reagents.

The degree of specificity of an antibody response varies with circumstances. There are few data on the point available from work with purified antigens but much from studies with pathogenic microorganisms. Comparison of antibody reactions to immunisation with strains of influenza virus $A$ have been made in horses, ferrets, and rabbits, and in human adults and children. Horse antisera show little specificity, neutralising to approximately the same titre strains that are widely separate when tested with ferret or rabbit immune sera. Rabbit sera in their turn detect differences between strains identical by ferret antiserum tests. Adult human antisera show a much broader (less specific) response than those from children under twelve.

In dealing with antibody to body constituents, notably red cells, the highest degree of specificity is obtained by iso-immunisation, i.e. immunisation of another individual of the same species. This method has been widely used in studies of fowl (Todd, 1930) and of bovine red blood cells (Ferguson, Stormont, and Irwin, 1942). Occurring under natural or accidental conditions in man it may give rise to a whole series of important clinical phenomena.

\section{EXPERIMENTAL AND CLINICAL DATA IN REGARD TO ANTIGENIC DIFFERENCES IN THE CELLS OF WARM BLOODED VERTEBRATES}

For reasons that have already been suggested, work in the field of antigenic differences between individuals has been largely dominated by the importance of such differences in regard to blood transfusion in human beings. A second stimulus to experimental work has been derived from attempts to replace a diseased organ by the same organ or tissue from a healthy donor and from studies of the limitations of transfer of malignant tumours from one host to another. The bulk of the work which will require review is concerned with these two related types of study.

It must be recognised that the available factual material is completely inadequate for any comprehensive discussion of the gene-antigen relationship. Practically all the material concerns " expendable" cells of mammals or birds, which have an elaborate system for disposing of worn-out individual cells and for dealing immunologically with foreign substances or micro-organisms. This introduces important complications which will be discussed later. What is badly lacking is any comprehensive data on antigenic variation in the protein or polysaccharide components of some simple organism with a sexual mode of reproduction such as Neurospora or Saccharomyces. There is no suggestion that such organisms can produce anything equivalent to an immunological response and the inter- 
pretation of results would be free of the necessity for considering the " marker" hypothesis to be dealt with later.

In the following sections an attempt has been made to collect the more important available material on gene-antigen relationships.

\section{(a) The human blood groups}

There is a much more extensive literature on the human blood groups than on any other genetically determined aspect of immunology and any theory of gene-antigen-antibody relationship is almost driven to this human material to find tests for its validity or otherwise. The following is a brief recapitulation of the position. Blood grouping is concerned with the recognition of certain antigenic determinants (chemical patterns) on the surface of red blood cells by the use of specifically reactive sera which may be obtained from normal individuals, from patients who have reacted abnormally to pregnancy or transfusion, or from animals that have been specifically immunised for the purpose. In all such tests it is found that red cells from certain individuals are agglutinated by some reagent in the serum while cells from others are not. It can be shown that the serum reagent is a globulin with such a configuration that it is bound specifically to a certain molecular pattern on the cell surface. When these globulin molecules have two or more reactive groups, they can serve as a bridge between two appropriate red cells causing their agglutination.

We can first consider what is known of the inheritance of the chemical patterns on the red cells without at present any regard for the significance of the reagents by which they are detected.

The classical blood groups, $\mathrm{O}, \mathrm{A}, \mathrm{B}$ and $\mathrm{AB}$ are differentiated by the presence of one or another of four possible patterns on the surface of the red cells of human beings. Two of these patterns, A and B, are straightforwardly detected by the appropriate agglutinin. $A_{2}$ is a less reactive form of $A$, only to be detected by a proportion of the sera which react with $A_{1}$ while $O$ was originally defined on purely negative characteristics. It is now known that $O$ cells have a corresponding pattern (also present to some extent in $\mathrm{A}_{2}$ and possibly other cells) which can be detected by appropriately chosen animal sera. Omitting very rare anomalies all human bloods fall into one of six patterns :-

$$
\begin{array}{llllll}
O & A_{1} & A_{2} & B & A_{1} B & A_{2} B
\end{array}
$$

The inheritance is usually interpreted as being dependent on four parallel allelomorphs $O, A_{1}, A_{2}, B$ of which $A_{1}, A_{2}$, and $B$ are dominant to $O$ and $A_{1}$ dominant to $A_{2}$. The constitution of the different phenotypes then is :-

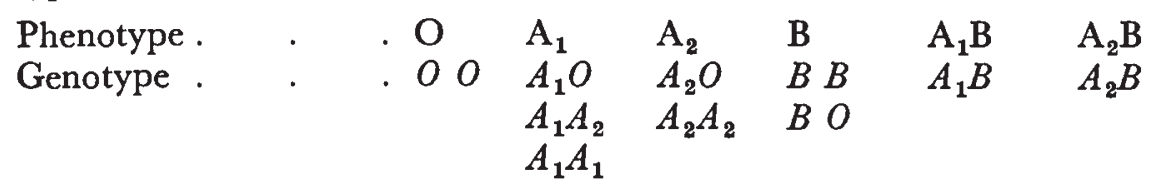


Quite early in the history of blood group investigation it was found that a proportion of group $\mathrm{A}$ individuals provided secretions (saliva, urine, or gastric fluid) containing the same antigen and therefore capable of " blocking " agglutination of their red cells by an anti-A serum. It is now known that the blood group substances in these secretions are associated with mucins or mucoids and serologically active mucoids of types $\mathrm{A}, \mathrm{B}$, and $\mathrm{O}$ have been prepared. The most suitable source is the content of pseudomucinous cysts of the ovary. All these mucoids are of very similar chemical character no difference being detectable in the polysaccharide " nucleus" (Morgan, 1947). Individuals can be divided into secretors and non-secretors according to whether the appropriate blood group substance is present or not in water-soluble form in their secretions. The difference is inherited in simple Mendelian fashion, secretor being dominant to non-secretor.

Serologically active mucins are of wide occurrence amongst the mammalia. Aminoff, Morgan, and Watkins (1946) have recently shown that individual pigs will provide either $\mathrm{A}$ or $\mathrm{O}$ type mucin from their gastric mucosæ. Monkeys of the genus Macaca have red cells which are unagglutinated by human $\alpha$ (anti-A) or $\beta$ (anti-B) isoagglutinins, but their secretions contain $\mathrm{A}, \mathrm{B}$, or $\mathrm{O}$ substance and their sera have $\alpha, \beta$, or no agglutinins, according to the same rules as human beings. This seems to indicate that the division of human blood cells into the A B O groups may be only a minor consequence of some deep-seated attribute of mammalian organisation.

With the development of methods for detecting $\mathrm{O}$ antigen, facts have been uncovered which require some modification of the classical theory of the A B O blood groups. In the first place secretors of blood group A or B who secrete A and B substances in a water-soluble form also secrete O-substance (Morgan, 1947). Secondly, Hirszfeld and Amzel (I940) claim to have demonstrated O-substance in the red cells of individuals "homozygous" for A or B by quantitative agglutination tests with natural bovine anti-O sera, and with high titre anti-O sera produced by the prolonged immunisation of goats with Shiga dysentery bacilli.

To explain these findings Hirszfeld (1947) has postulated the existence of "pleiades" of blood cell types, arbitrarily designated O.... $A_{5} A_{4} A_{3} A_{2} A_{m} A_{r} A_{j} \ldots A_{c}$ and $O \ldots B_{2} B_{m} B_{r} B_{j} \ldots B_{c}$ in decreasing order of reactivity with anti-O serum. These pleiades represent successive mutations from the original primitive group $O$ towards the limiting cases of types $A_{c}$ and $B_{c}$, which contain no O-substance in the cell, but do contain anti-O isoagglutinins in the serum. Individual genes close together in the transition series show the phenomenon of partial dominance whereas those farther apart show absolute dominance. Thus red cells of individuals of the homozygous genotype $A_{j} A_{j}$ and of the heterozygous genotype $A_{j} O$ react equally well with anti-O serum because the gene $A_{j}$ which 
confers a weak but definite $O$ character to the cells, suppresses more or less completely the effect of any genes tending to confer stronger $\mathrm{O}$ character. This concept of gene structure will satisfactorily explain the occurrence of $\mathrm{O}$ substance in most human red cells, but Hirszfeld's results should perhaps be confirmed with either a human anti-O serum, or a less completely heterologous serum, such as for instance, the anti-O serum produced in rabbits by Morgan and Waddell (1945).

The MN series of blood groups is determined by the use of sera from rabbits which have been immunised with human cells. The sera are then absorbed with heterologous human cells to remove all but the required $\mathrm{M}$ or $\mathrm{N}$ agglutinins. With such reagents cells can be divided into three groups according as they are agglutinated by $\mathrm{M}, \mathrm{N}$, or both sera. No cells are found which are inagglutinable by either serum. The inheritance is independent of sex or of any other type of blood group and is of the simplest Mendelian character.

$\begin{array}{lllllll}\text { Phenotype } & \cdot & \cdot & \text {. } & \mathrm{M} & \mathrm{N} & \mathrm{MN} \\ \text { Genotype } & \cdot & \cdot & \text {. } & M M & \mathcal{N N} & M \mathcal{N}\end{array}$

Certain pig sera agglutinate about two-thirds of a random collection of human blood cells. The antigen $\mathrm{P}$ is distinct from any of the other blood groups and is inherited as a dominant Mendelian character.

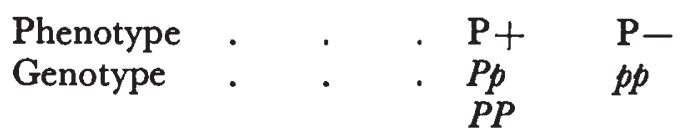

Recent work (Snyder, 1946) indicates that minor differences in $\mathrm{N}$ antigens and in $P$ antigens essentially similar to the $A_{1}-A_{2}$ relationship can be detected by refined methods.

Finally the complex and clinically important group of $\mathrm{Rh}$ antigens must be considered. A significant new antigen in human cells was first demonstrated by Levine and Stetson (1939) as a result of a severe transfusion reaction in which donor cells of the same group (O) as the patient had been used. The recipient was shown to have in her serum an agglutinin active against about 85 per cent. of human group $O$ cells. Soon afterwards it was shown that the antibody produced by immunising rabbits or guinea-pigs with Rhesus monkey blood agglutinated the same 85 per cent. of human cells. These were therefore described as $R h+$ cells the other ${ }^{5} 5$ per cent. of individuals having $\mathrm{Rh}-$ cells. Clinically, sera having this type of activity were observed after repeated blood transfusions, some at least of the donors being $\mathrm{Rh}+$ and the recipient $\mathrm{Rh}-$, or in women, themselves $\mathrm{Rh}-$, who had borne more than one $\mathrm{Rh}+$ child. In the latter cases the $\mathrm{Rh}+$ infants were in a proportion of instances subject to more or less severe symptoms of blood destruction shortly after birth.

The inheritance of the two blood cell types was first ascribed to 
the existence of two allelomorphs $\mathrm{Rh}$ and $\mathrm{rh}, \mathrm{Rh}$ being dominant to rh. This simple statement is sufficient to cover most of the occurrences, but more detailed study gives a much more complex picture. Fisher's interpretation (Race, 1944, r946) is that the inheritance is determined by genes situated at three closely adjacent loci on a single chromosome, each gene having two common allelomorphs and possibly other rare ones. The genes are $C, c\left(C^{w}\right)$; $D, d\left(D^{u}\right) ; E, e$. In England the three commonest combinations are $C D e\left(R_{1}\right), 4^{6}$ per cent. ; cde $(r), 3^{8}$ per cent. ; $c D E\left(R_{2}\right), 12 \cdot 8$ per cent. Typical $\mathrm{Rh}$ positive genotypes are $C D e / C D e, C D e / c d e$, $c D E / C D e$, while the $\mathrm{Rh}$ negative formula is cde/cde, or any other combination containing ..d../..d..

Each allelomorph corresponds to and determines the formation of an antigen on the surface of the red cell, and each antigen may, on introduction into an individual lacking it in his own cells, provoke the appearance of the corresponding antibody. There seems to be no doubt that the $\mathrm{D}$ antigen is intrinsically more likely to produce antibody than any other of the antigens, and the standard $\mathrm{Rh}$ antiserum which agglutinates 85 per cent. of cells from a normal European population is anti-D.

The details of the process by which a foetus of genetic composition, $C D e / c d e$, can stimulate its cde/cde mother to produce anti-D with subsequent passage of the anti-D to the foetal circulation are still far from clear. The number of cases of damage to the foetus is far smaller than the number of pregnancies potentially capable of producing it. A repetition of the antigenic stimulus, e.g. a second or subsequent pregnancy of the same type, increases the likelihood of antibody production. Individuals apparently differ in their capacity to respond to a potential antigenic stimulus despite the fact that they are nominally of the same $\mathrm{Rh}$ genetic constitution. In an experimental study of the artificial immunisation of $\mathrm{Rh}$ negative (cde/cde) volunteer donors with $\mathrm{Rh}$ positive ( $c D E / c D E)$ cells, Wiener and Sonn-Gordon (1947) obtained only two satisfactory sera from nine subjects. When immunisation was prolonged, anti-D was first produced, followed by anti-E antibody.

The immunising potency of the antigens corresponding to the various $\mathrm{Rh}$ genes varies considerably. Of those corresponding to the dominant genes $\mathrm{C}, \mathrm{D}$, and $\mathrm{E}$, all will provoke antibody formation whether present in the homozygous or heterozygous condition; but $\mathrm{D}$ is a more effective antigen than $\mathrm{C}$, which is in turn better than $\mathrm{E}$. The effect of the antigens corresponding to the recessive genes is inhibited in the heterozygous condition and, even when cells of an individual who is homozygous recessive for one of the genes are used to immunise the corresponding homozygous dominant individual, they are poor antigens. Consequently anti-e, anti-d, and anti-e sera are all very rare.

There is a very extensive recent literature on the subject and as 
yet there is no general acceptance of the nomenclature based on Fisher's scheme. Wiener, Sonn, and Polivka (1946) use the older nomenclature and consider that there are six major and perhaps some minor allelic genes on the one chromosome, the " $\mathrm{Hr}$ factors" (i.e. cde in the alternative notation) being related to the $R h$ factors $(C D E)$ as $M$ is related to $\mathcal{N}$.

It appears that the four groups of antigens $(\mathrm{ABO}, \mathrm{MN}, \mathrm{P}$, and $\mathrm{Rh}$ groups) do not exhaust the possibilities of detecting all differences between individuals, but discussion of other differences, mostly based on the reactions obtained with a single serum, is hardly called for in the present context. From all the work that has been covered the main deduction to be made is simply that variation in the nature of a single gene is sharply and regularly reflected in the specific immunological pattern of a red cell surface component. This holds for at least four unrelated series of genes.

From the general point of view, the $A B O$ groups are the most interesting, for they are determined by the use of natural isoagglutinins, i.e. antibody-like agents not resulting from artificial or accidental immunisation and effective against red cells from certain other individuals of the same species. In man the agglutinin content of any individual serum is determined by the rule that only those agglutinins which do not affect the person's own cells are present. A group A person has $\beta$ agglutinin reacting with $\mathrm{B}$ or $\mathrm{AB}$ cells, a group $\mathrm{O}$ individual both $\alpha$ and $\beta$, and so on. This must, however, be qualified in regard to anti-O agglutinins. Sera can be found (amongst natural bovine sera) or prepared (e.g. by prolonged immunisation of goats with Shiga dysentery bacilli) which specifically agglutinate human $\mathrm{O}$ cells, but natural anti-O isoagglutinin is found only very rarely in human beings (Landsteiner and Witt, 1926).

Three explanations have been put forward to account for the occurrence of the natural human isoagglutinins.

(I) It is characteristic of the globulin molecules produced by the human body, once it is adapted to extra-uterine existence, that a proportion of them can be specifically adsorbed to $\mathbf{A}$ and $\mathbf{B}$ cell substances, and will therefore act as agglutinins. Essentially this is an accidental occurrence as fortuitous as the fact that certain ox sera will agglutinate human $\mathrm{O}$ cells, a mere matter of the chance complementary arrangement of globulin and polysaccharide patterns. When genetic conditions produce A substance in the cells, secretions, and serum of an individual, this will react with the a agglutinin fraction of serum globulin " absorbing" it out of the serum and leaving only the $\beta$ component. In similar fashion $B$ substance will remove $\beta$ leaving $\alpha$, while in an $\mathrm{O}$ individual both $a$ and $\beta$ can remain.

The difficulty of this theory of Bernstein is that it tacitly assumes in $\mathrm{A}, \mathrm{B}$, and $\mathrm{AB}$ individuals a continuing production of agglutinin which is steadily taken up and removed from serum by cells, or by other sources of blood group substance. It would therefore be expected 
that the cells would be prone to spontaneous agglutination or at least give evidence of globulin coating by Coombs test (Coombs, Mourant, and Race, 1945). In fact there is no suggestion of this.

The smallest modification of this hypothesis that might bring it into line with this absence of the evidence for existence of $e . g$. $a$ agglutinin production in an $A$ individual is to assume that the existence of A substance in the agglutinin-producing cells automatically prevents the liberation of the corresponding a agglutinin or, more correctly, of those globulin molecules which have a configuration causing them to act as a agglutinins. As is so often the case in speculative hypotheses in this general field, it must be confessed that on present knowledge it would be almost equally legitimate to assume that the presence of A substance in the cell would stimulate it (in immunological fashion) to produce excessive $\alpha$ agglutinin as to make the present assumption that it will inhibit a agglutinin production.

(2) The $\alpha$ and $\beta$ agglutinins are essentially similar to other antibodies in being produced in response to an appropriate immunological stimulus. This stimulus is provided at the time of birth, and implants in the antibody producing cells a capacity to produce agglutinin which fades out very slowly after childhood.

The features that favour this hypothesis are :-(I) The disappearance in the first ro days after birth of the low concentration of iso-agglutinins received across the placenta and the appearance of agglutinin corresponding to the infant's genotype at about ro days. (2) The existence of a wide range of titres of iso-agglutinin, as of any common acquired antibody. (3) The peak of iso-agglutinin titre in childhood declining slowly thereafter. (4) The fact that the agglutinin titre can be raised by "immunisation" of volunteers with group specific substance, and (5) the correspondence in specificity of $\alpha$ and $\beta$ iso-agglutinins with those produced in rabbits with semi-synthetic antigens (Morgan and Watkins, I945).

The major and, at the moment, insuperable difficulty of this hypothesis is to identify the immunological stimulus. To take an infant born of two $\mathrm{O}$ parents and therefore $\mathrm{O}$ itself, we have to assume that about the time of birth both $\mathrm{A}$ and $\mathrm{B}$ antigens are introduced into the circulation in sufficient amount to impress a lasting antigenic stimulus on all the cells concerned in this particular type of globulin production. There is no known source of such A and B substances, and until such a source is established the hypothesis will remain untenable.

(3) The last alternative which is supported by Landsteiner (1946) is that the natural agglutinogens and agglutinins must both be accepted as being genetically determined without the introduction of any immunological conceptions whatever. This is an intellectually unsatisfying conclusion and we feel certain that it will eventually be replaced, but at present it is the only available interpretation. 


\section{(b) Red cell antigens in other mammals}

Normal iso-agglutinins can be found in the sera of several other mammals including cattle, sheep, pigs, and horses, but there is not the same complete reciprocal relationship as in human beings. In horses the reiationship holds for only two agglutinogens and agglutinins, four other iso-agglutinins occurring in only a small proportion of the animals which lack the corresponding agglutinogen.

Wiener (1943) has summarised the available data on intraspecific variation in red cell antigens in mammals. In general, the antigens are classified by their reactions with antisera prepared either in rabbits, or by iso-immunisation of another individual of the species under study. In either case the presence of a specific antigen accompanies the dominant allele of a specific gene.

It is of interest that an antigen responsible for individual differences in one species may be characteristic of the species as a whole in another. The human blood group A substance is present in all sheep cells while an antigen very similar to B is present in the cells of rabbits, cattle, and cats. The $M$ antigen is found in all rhesus monkeys. This is probably no more than an indication that there is a relatively limited number of molecular patterns which can be developed by the mucins or other components of the cell surface.

Todd and White (1910) showed that there were large numbers of different antigenic types in cattle blood, and this work has been elaborated by Ferguson (1941) and later by Irwin and his colleagues. Owen, Stormont, and Irwin (1947) have shown that there are at least thirty inheritable cellular antigens in cattle, detectable by hæmolysin tests with suitably prepared cow and rabbit sera. Many of the differences between individuals are minor ones detectable only with low dilutions of antiserum. The majority of the antigens appear to be separately inherited, although certain are linked in such a way as to indicate that they are the product of allelic series of genes or of closely linked genes.

An extremely interesting incidental observation from this work on cattle has been provided by Owen (1945) in his discovery of the existence of erythrocyte mosaics in calves from certain multiple births. The production of "freemartins," sterile heifers, in cases where male and female twins develop a common placental circulation, is well known. Under circumstances where twins (or in one instance quintuplets) have a common circulation, two types of red cell may be found in both the twins for life. One corresponds genetically to its own cells, the other to its twin's. This finding seems to have been completely established and has the important implication that cells "foreign" to the host may be tolerated indefinitely provided they are implanted early in embryonic life. 


\section{(c) Red cell antigens in birds}

Todd (1930) obtained evidence of multiple antigenic factors in the blood cells of fowls, these being inherited as simple Mendelian dominants. In most of his work he used polyvalent iso-immune sera, which were appropriately absorbed for use in critical tests. If such a serum was absorbed with cells from both parents, it regularly failed to agglutinate the cells of the offspring although active against all or most unrelated birds. Wiener (1943) considered that Todd's results could be interpreted on the basis of a small number of factors determined by three allelic genes and another separate pair of genes.

Irwin, Cole, and Cumley of the University of Wisconsin have in the last ten years made extensive studies of genetically controlled interspecific variation in pigeons and doves. They used antisera produced in rabbits to investigate the antigens of the erythrocytes of several species of pigeons and doves, of various species hybrids, and of backcross matings of these hybrids with one or both of the parental species.

The findings may be summarised as follows (Irwin and Cumley, I943; Irwin, 1946). For any two species there are in the erythrocytes both common and species-specific antigens which can be detected with appropriate antisera. The antigens observed were all "major" antigens, i.e. they were detected with antisera diluted $\mathrm{I} / 6 \mathrm{O}$ and usually I/200,000 or higher. Thus, in the pearlneck dove (Streptopelia chinensis)-ring dove ( $S$. risoria) hybrid there may be present antigens $A B C D$, whereas pearlneck only has $A B C$ and ring dove $B C D$. $A$ is specific to pearlneck and $D$ to ring dove, $B$ and $C$ being common to each. Backcrosses of the $F_{1}$ hybrid to the parental species show that species-specific antigens are inherited as though they were determined by dominant genes. The pearlneck-ring dove hybrid backcrossed to ring dove shows that there are at least ten erythrocyte antigens specific to pearlneck. Since the genes determining these are heterozygous in the $F_{1}$ while the ring dove parent is homozygous recessive, the backcross progeny segregate in a one-to-one ratio of presence or absence of each of the ten pearlneck-specific antigens. Backcrossing in the other direction is difficult, since the females, neither of pearlnecks, nor of the species hybrids, produce viable offspring. Extending the same method of immunogenetics, Irwin and Cumley have found similar shared and species-specific erythrocyte antigens in several other species of dove and pigeon.

In all the instances so far described, in humans, cattle, birds, etc., a one-gene-one-antigen relation obtains, although in their earlier papers, Irwin and Cumley (1943) did not postulate such a relationship, but assumed only that each of the ten species-specific antigens of pearlneck, for instance, is produced by one or more genes on as many chromosomes. However, Irwin and Cumley (1945) have described " hybrid substances" in the cells of species-hybrids in doves, 
i.e. cellular antigens not present in either parental species. When antisera to pearlneck-ring dove hybrids were absorbed with cells from both parental species, antibodies specific for the hybrid substance complex remained. They explained the phenomenon by assuming that hybrid substance is produced by interaction of genes each of which in the parental species produces only species-specific antigens. We feel that this conception may need modification if and when the antigens concerned are chemically characterised. Irwin and Cumley (1945) have themselves shown that the hybrid substance can be differentiated into two well-defined antigens with a possible third. One is associated with their antigen d in, the other with any one of several antigens. It seems possible that, although only the parental antigens are induced in the hybrid cells, the new necessities of fitting in the various molecular types into the cell surface mosaic may fortuitously require that new antigenic patterns appear. These would then be determined by stereochemical factors and only in a very indirect way by gene action.

It is not inconceivable that such reorganisation of the cellular surface might even allow the hybrid cells to be antigenic when injected into one or other of the parents. McGibbon (1944) obtained analogous results with duck hybrids, and he was in fact able to produce antibodies against the hybrid substance in the actual parents of the hybrids carrying this new antigen.

\section{(d) Species specificity of proteins and haptens}

The specificity of the cell antigens which we have just been discussing depends upon protein-free polysaccharides and lipids which, when isolated from their usual protein carrier, are highly active in vitro but fail to stimulate the production of antibodies. For such substances Landsteiner (I92 I) proposed the term hapten.

There is abundant evidence, which has been summarised by Landsteiner (1946), that proteins are also species-specific. The only systematic investigation of the inheritance of protein specificity is that carried out by Cumley, Irwin, and Cole (1943) on the serum proteins of their dove hybrids. They concluded that species hybrids possessed the proteins of each parent species and that the proteins are controlled by gene action and consequently segregate in backcross hybrids, just as do cellular agglutinogens. The genes responsible for serum antigens appeared to assort independently of those determining the red cell agglutinogens of the same species.

Apart from earlier reports which have not been substantiated (Landsteiner, 1946) only one instance of apparent intra-specific differences in protein has been described. Cumley and Irwin (I942) found individual differences in human sera by means of precipitin tests with absorbed rabbit antisera that may be referable to proteins; but this work needs confirmation. 
Landsteiner (1928) has pointed out that there appear to be two systems of species specificity in animals. In the case of proteins the serological and chemical properties in general parallel closely the zoological or bacteriological relationships and the changes are gradual, intra-specific differences being rare or non-existent. On the other hand, the complex antigens consisting of combined protein and hapten are characterised by heterogenetic reactions, which reveal apparent relationships between widely varying species (e.g. the Forssman antigens), and by well-defined heritable intra-specific differences, such as those of red blood cells and tissue cells and the type specificity of many bacteria. The relationship between chemical structure and the ease with which mutations can be recognised by changed serological specificity may throw considerable light on the mechanism of evolution. If Tatum and Lederberg's (1947) demonstration of recombination of characters in mixed cultures of the bacterium Escherichia coli is confirmed and amplified, bacterial genetics may provide the most direct attack on this problem.

\section{TISSUE TRANSPLANTATION}

Although the study on one particular form of tissue transplantation, namely the transfusion of red blood cells, has from the first been regarded as a province of immunology, it is only recently that it has been generally accepted that the response of a host to the transplantation of homologous or heterologous normal or tumour tissue is primarily immunological.

In general, if living skin cells are grafted from one site to another on the same individual (autograft) they become attached to the raw area, proliferate and eventually reconstitute the normal skin epithelium. If the cells from another unrelated individual of the same species (homograft), or of another species (heterograft), are used, preliminary attachment occurs, but in 10-14 days there are signs of inflammatory activity beneath the grafts which rapidly separate and necrose.

The most comprehensive account of the results of tissue transplantation is contained in Loeb's (1945) The Biological Basis of Individuality. Throughout his work Loeb was very impressed with the lymphocytic infiltration which occurs around all tissue grafts except autografts. He considered that this reaction, and the subsequent destruction of tissue in homo- and hetero-transplantation, was due to the action of " individuality differentials " of the transplant upon the host. He described such differentials as homotoxins and heterotoxins and thought that the effect was a direct toxic action of the graft upon the host, immune reactions being of minor and secondary importance. There is little in Loeb's work, however, which could not be interpreted in terms of the immune response as the principal mechanism, and not a secondary effect. It appears to us that the "individuality differentials" of which he speaks are in fact the antigens of the grafted tissue relative to the particular 
host concerned. Loeb and his collaborators carried out experiments involving multiple grafts of thyroid and cartilage ; but they examined the sections only a few days after the second transplantation, and used organs from different donors from the first- and second-set grafts ; it is thus not surprising that they failed to obtain conclusive evidence of the immunological nature of the response to homotransplants.

However, Medawar's studies of homologous skin grafts in humans (Gibson and Medawar, 1943) and rabbits (Medawar, 1944, 1945) conclusively established the immunological nature of the reaction of a host to a homologous tissue graft. He adopted as his criterion of the immunological nature of the reaction the difference in the behaviour of two skin grafts from the same donor implanted on another animal at an interval of I4 days. He found a greatly accelerated reaction to such second set grafts, but not to second grafts from another donor animal. In addition he was able to show that the "dosage" of donor cells, i.e. the size of the graft used, influenced the intensity of the response to a second graft from the same donor. The bigger the primary graft the more active the second response. His interpretation is that in response to the primary stimulus an altered state of immunological reactivity is induced which in 12-14 days results in the destruction of the graft. A second graft from the same source finds the reactive state already established and the destructive process begins as soon as the graft cells commence to multiply.

In the field of tumour transplantation the results are not quite so straightforward. Gorer (1938, 1942) insisted that immunity to tumour transplants was identical with immunity to transplants of normal tissue, both being primarily immunological reactions. In studies of sarcoma and leukæmia in mice he produced antibodies in the serum of mice of a resistant strain by the intraperitoneal or subcutaneous inoculation of tumour tissue. When mixed with tumour tissue and inoculated into susceptible mice the antibody exerted a protective effect. However, such experiments as those of Greene (I94 I $a$ and $b$ ) on the successful transplantation of a variety of heterologous cancerous tumours to the anterior chamber of the eye of rabbits, rats, and guinea-pigs, when transplants of normal adult heterologous tissue failed, indicated that some additional factor entered into the picture. Greene and Murphy (1945) found that homologous and heterologous transfer of tumours was a failure until the tumours became autonomous, i.e. until they became invasive or cancerous. With the attainment of autonomy, genetic and species barriers were eliminated and tumours transplanted to unrelated animals and foreign species would grow.

While the immunological nature of the reaction of a host to a homologous or heterologous tissue transplantation was widely recognised only comparatively recently, it has long been realised 
that the basis of the differences between host and donor tissue was genetic. Loeb and Wright (1927) showed that inbred brother-sister lines of guinea-pigs could be rendered sufficiently homozygous to accept grafts from other individuals of the line, but not from animals of a second inbred line. $F_{1}$ hybrids would accept grafts from animals of either line, but grafts from the hybrids would not take in animals of either pure line. Studies with rats and mice (e.g. Little, I94I; Bittner, I944) have given similar results.

The most effective attack upon the problem of tissue transplantation as a genetically controlled immunological process is that of Medawar (1945), who by making simultaneous "fitted" grafts from each of 25 heterozygous rabbits to the other 24, established that in these animals there were at least 127 "skin transplantation groups" governed by at least 7 antigens. In a subsequent paper Medawar (r946b) demonstrated that while rabbit's red blood cells cannot be used for immunisation against skin grafts, the leucocytes do share a number of antigens with skin tissue, and effective immunisation against homologous skin grafts can be obtained by the intradermal inoculation of suspensions of that rabbit's leucocytes. Medawar was unable to demonstrate antibodies by serological methods, but by making mitotic figure counts in transplanted autografts and first and second set homografts, he was able (Medawar, I $946 a$ ) to show that the antibody generated by skin homografts brought cell division in the grafts to a standstill.

Medawar and McDonald (I947) have recently investigated the genetic background of skin transplantation immunity in mice, using two strains, one of 30 and the other of 22 successive generations of brother-sister mating. Neither of these strains was genetically uniform so far as genes controlling skin antigens were concerned. As might be expected, skin transplanted between related, but not homozygous, mice can sometimes survive despite clear evidence of an immune response. Here presumably a single "foreign" antigen has failed to elicit a vigorous enough immunological response.

It is of interest to speculate on the basis of the immunological intolerance of foreign tissues. Professor Medawar tells us he was unable to demonstrate any damaging effect on tissue cultures of donor rabbit skin with sera cells or tissue extracts of rabbits heavily immunised by the repeated application of large grafts. In vivo his findings suggested that the effect of immunisation was to prevent the multiplication of the donor cells.

Harris (I943 $a$ and $b$ ) carried out experiments with roller tube tissue cultures of various organs of rats and mice. He found that mixed cultures of rat and mouse cells survived with normal morphology in normal rat serum. If, however, serum from rats which had been previously immunised with mouse tissues was used in such mixed cultures specific destruction of the mouse cells resulted. Though these experiments differ in important respects from Medawar's they 
may indicate when taken along with his that the immune reaction is not mediated by normal antibody, but an agent of the type that has been postulated for the production of tuberculin hypersensitivity. One might assume that the mononuclear inflammatory cells in the neighbourhood of the graft were specifically stimulated, by contact with the donor antigen against which they had been sensitised, to liberate the same pharmacologically active substance as is concerned in the tuberculin reaction, and that this substance is responsible for the inhibition of multiplication. The suggestion has at least the merit that it is amenable to an experimental test.

\section{THE INFLUENCE OF GENETIC FACTORS ON THE IMMUNE RESPONSE}

The only type of immunological reactivity in which the role of heredity has been extensively studied is allergy in man. Twin studies (Hanhart, 1940) revealed that of $7 \mathrm{I}$ pairs of identical twins there was an 80 per cent. concordance in respect of hay fever, 6o per cent. in respect of migraine and 28.6 per cent. in respect of asthma. Numerous investigations have been made of the role of heredity in human allergy, and a genetic analysis of the available data has been made by Wiener et al. (1937). When the age of onset of allergic disturbances (that is hay fever, asthma, urticaria or food allergy) is studied, two peaks are found, one in early childhood and one in the third decade of life. Wiener t $t$ al. suggested that the tendency to develop allergic disease is transmitted by a single pair of allelomorphic genes, $\mathrm{H}$ and $\mathrm{h}$, where $\mathrm{H}$ denotes absence of allergy and $\mathrm{h}$ allergy. There are three genotypes- $\mathrm{HH}$, who are quite normal, hh, who develop symptoms of allergy before puberty, and the heterozygotes $\mathrm{Hh}$. The last are either normal transmitters (five-sixths) or develop allergic disease after puberty (one-sixth). One difficulty of Wiener's hypothesis, so far unexplained, is the observed excess of males over females in those developing allergic disease before puberty.

To us this interpretation seems unduly simplified. Many allergists consider that probably every individual has at some time shown allergic symptoms of one sort or another, and it is quite certain that the conditions of exposure to the sensitising substance play an important part in determining clinical sensitisation. There is no question that genetic factors are deeply concerned, but it seems highly improbable that the tendency to allergic disease depends on a variation in a single gene.

A few investigations have been made in animals. By selective breeding Chase (194I) was able to demonstrate that the susceptibility of guinea-pigs to skin sensitisation with simple chemical compounds was influenced by heredity. Using $d$-nitrochlorobenzene and poison ivy in succession, he found that there was a rough accordance between the sensitivity developed to the two compounds although there were 
several instances of discrepancy. Similarly, Jacobs, Kelley, and Sommers (r94I) were able to establish a strain of guinea-pigs, practically all members of which could be sensitised readily and strongly with allyl isothiocyanate, a compound which will sensitise only a small percentage of unselected animals.

It is common in experimental immunisation to find that one animal develops much higher antibody titres than another after similar courses of inoculations. There have been few investigations made to see whether the capacity to produce high titre or low titre antibodies to various types of antigens is controlled by genetic factors. One factor underlying this variation is the variable genetically controlled presence of the hapten concerned in the tissues of the laboratory animal used. For instance, Wheeler, Sawin, and Stuart (1939a) proved that the occurrence of A substance in the tissues of rabbits is inherited as a dominant Mendelian factor. Animals possessing A substance failed to produce a-agglutinins on the injection of human A-erythrocytes, but animals of an inbred strain lacking this character produced uniformly high titres. The same authors (1939b) found that the capacity of rabbits to produce antibodies for the M-antigen in human red cells appeared to be inherited; but here lack of ability to produce antibody could not be traced to the presence of $M$ substance in the animals. Lewis and Loomis (1928) tested the members of four families of inbred guinea-pigs for their ability to form antibodies to cattle and sheep red blood cells, to $S$. typhi, and to $B r$. abortus. They found that when single small or moderate doses of antigen were used, so that the primary response only was observed, familial differences were clear-cut, two families being good, and two poor, antibody producers. With repeated doses or very large single doses, which involved the secondary response, the results were irregular.

The available evidence indicates that genetic constitution does play a part in deciding the efficiency of the immune response, but the position is complex and the reactions of the same animal to different antigens may differ greatly.

\section{A THEORETICAL DISCUSSION OF ANTIBODY PRODUCTION IN THE LIGHT OF MODERN THEORIES OF GENE AND ENZYME ACTION}

Any discussion of the application of immunological methods to genetic studies must be incomplete if it is limited, as previous reviews have been, merely to the provision by immunological methods of data about phenotypic structure not recognisable by other means. It is of greater interest, and of potentially greater practical importance, to attempt to elucidate the process by which foreign molecular patterns give rise to characteristic immunological responses, including sensitisation phenomena as well as production of classical serum antibody.

In most respects the discussion which follows is based on a monograph on "Production of Antibodies," published by one of us in 1941. 
Fuller details of the experimental work on which it is based will be found in that monograph, a second edition of which is in preparation. The present approach is, however, along quite distinct lines, being largely influenced by the rapidly developing new conceptions of gene and enzyme action.

Our procedure will be to outline first what we regard as the relevant facts in regard to the physiology of antibody production, with special reference to the types of cells concerned in the process. This will be followed by an attempt to restate in somewhat modified form the concept of antibody production as an adaptive enzyme process. The argument will be almost wholly at the biological level and will centre in the conception that the cells concerned in antibody production have two important functions : (i) the removal of effete body cells and components and (ii) the removal of, and immunological response to, invading micro-organisms.

\section{(a) The production of antibodies}

There is more than one type of antibody. An anti-pneumococcal horse serum contains its specific activity almost wholly in the form of a globulin of high molecular weight, approximately $1,000,000$, and of great asymmetry. Diphtheria antitoxin produced in the same species is predominantly a function of molecules similar to normal $\gamma$ globulin and of molecular weight about 180,000 . In man and rabbit nearly all antibodies are of this latter character, but even so there are considerable and perhaps fundamental differences from one type of antigenic response to another. Under the circumstances, it is extremely difficult to develop any general theory of antibody production. There is an almost infinite number of possible antigens and three different mammals-man, horse, and rabbit-whose immunological responses are of major practical or theoretical importance. Unfortunately, there is probably no single combination of antigen and antibody producer in which all the relevant points have been investigated. Our list of the aspects of the problem, which have to be covered by any adequate antibody theory, will necessarily be drawn from a rather wide range of antigenic responses in more than one host species. As far as possible they will be taken from examples in which "normal" antigenic stimuli have been used. There can be no reasonable doubt that the antibody mechanism is something which has been developed as an increasingly effective means of dealing with bacterial invasion. As such its efficiency has probably been maintained at a high level, since any breakdown will sharply diminish survival chances. It will presumably therefore function most normally when the antigen used as stimulus is a bacterial product such as toxin or toxoid, or bacterial bodies themselves.

Let us take the reactions observed in rabbits immunised with, say, staphylococcal toxoid on the one hand, and a bacterial vaccine on the 
other, as standard, and where necessary use more convenient evidence from other systems. We may then state the essential characteristics of antibody production as follows :-

(I) Antibody is physically similar to the $\gamma$ globulin of normal serum (or exceptionally to some other normal globulin), differing in that each molecule possesses one or more modified areas of surface which react specifically with certain molecular patterns of the corresponding antigen. The relation is a complementary one not yet expressible in physical terms, but legitimately pictured as a lock-key or die-coin relation.

Several types of evidence support the existence of antibody incapable of producing the usual aggregation reactions and detectable only by indirect means. It is usual to regard this antibody as univalent in the sense of having only one specifically reactive group per molecule.

(2) Antibody is produced only in response to the entry of antigens into the parenteral tissues of the body. Antigens are macromolecular or particulate in character ; most are protein or complexes of other types of substance with protein. It may be that all antigens are either protein or capable of combining with the protein of the antibody producer. It is still possible, however, that some complex biological molecules free from protein may function as antigens in their own right. In general, any protein (or other macromolecular substance) is antigenic if $(a)$ it is not normally present in the animal immunised; (b) it can be broken down into disposable units by the tissues of the animal ; and $(c)$ it is not too rapidly eliminated from the body. There are wide variations in the ease with which antibodies are produced against different antigens.

(3) With "good" antigens the time aspect of antibody production varies characteristically according to the nature of the antigen. On the one hand, a toxoid given in a small to moderate dose provokes no antitoxic response, but a second similar inoculum given say 14 days later provokes a rapid sharp response beginning in 2-3 days and reaching a peak at 7 days. On the other hand, a particulate antigen gives rise to a response commencing 4-7 days after injection and reaching a peak at I0-1 4 days.

The reason for these differences is not fully determined. The most important difference is probably that the toxoid molecules are in a condition to be taken up immediately and almost simultaneously by the antibody-producing mechanism. Particulate antigens, e.g. bacteria, probably undergo a rather prolonged process of breaking down before the antigenically effective elements are available ( $c f$. Burnet, I94I).

(4) With any type of antigen, an animal which has once been immunised responds more rapidly and effectively to a fresh stimulus with the same antigen than a normal animal.

(5) Antibody is produced by mesodermal cells including the interrelated types known as large and small lymphocytes, plasma cells, histiocytes and cells of the reticulo-endothelial system. Such 
cells characteristically accumulate in the filtering mechanisms of the body, notably the lymph nodes and spleen, but also in the liver, bone marrow, and lungs. Lymphocytes appear to be a major source from which formed antibody (against bacteria) is liberated into the blood.

(6) Antibody in the circulation is being constantly removed at a rate proportional to its concentration with a "half-life" in some instances of about 2 weeks.

(7) Antibody production following an antigenic stimulus rises to a peak and then diminishes; but it continues at a diminishing rate for long periods. It seems to us that there is adequate evidence that antibody production continues after the antigen has been completely eliminated from the body. This, however, is by no means generally admitted. The theories of antibody production still current demand that antibody shall be produced only so long as the "antigenic determinants," at least of the antigen, remain in the body as a template for the production of the specific antibody pattern.

(8) Arising from (7) we must assume that antibody production is a function not only of the cell stimulated by contact with antigenic molecule or particle but also of its descendants. The average life of a lymphocyte is less than 24 hours.

(9) The antibody globulin molecules produced by a standard antigenic stimulus in a given species of animal are not uniform. They vary in two ways :-

(a) Absorption with related but not identical antigens will show that there are at least minor differences in specificity amongst the antibody molecules in the immune serum.

(b) The character of the antibody population differs according to the age of the animal and the intensity and time distribution of the antigenic stimulus.

\section{(b) The cells concerned in antibody production}

There is still controversy as to the actual cells involved in antibody production in mammals, but the competitors for this function are, so far as we are aware, limited to three types-macrophages (histiocytes, cells of reticulo-endothelial system), lymphocytes, and plasma cells. All these cells appear to be relatively undifferentiated descendants of the primitive mesenchymal cells (reticular cells) that are found in loose connective tissue, lymph nodes, spleen, etc.

The picture presented by histological textbooks (Maximow and Bloom) is of persisting relatively quiescent reticular cells which can, under appropriate conditions proliferate, producing either macrophages or medium or large lymphocytes. Both these types of cell are abundant; under ordinary circumstances they produce by mitosis cells like themselves, but the large lymphocytes can give rise to small lymphocytes or plasma cells ; both of these appear to be end cells 
not capable of further proliferation. There is some evidence that lymphocytes can, under certain circumstances, develop into macrophages. According to Maximow, the hæmocytoblast, from which all the red and white blood cells are derived, is indistinguishable from the medium lymphocyte, and the line of development which its progeny follow is determined essentially by internal environmental faciors.

It is certainly withın this closely interrelated group of cell types that antibody production occurs and, from the histological evidence of transitional forms, it would seem likely, first, that cells of slightly differing character within the group might all be responsible for antibody production under appropriate stimulus and, secondly, that the type of antibody produced might well differ according to the type or stage of specialisation of the cells responsible for its production.

It is necessary to recognise the existence of several different types of specific immunological reactivity each presumably mediated by what can legitimately be called antibody molecules. Those antibodies which provide, with the corresponding antigen, aggregation reactions of various sorts easily studied in vitro have been most intensively studied. For obvious reasons there is a tendency to centre all discussions of the nature and origin of antibodies in this particular type. This is legitimate enough provided the existence of other types of antibody, e.g. those concerned in the common allergic conditions of man, or responsible for tuberculin and similar types of sensitisation, are kept in mind. In fact it is only in regard to antibacterial circulating antibody, agglutinin or precipitin for specific polysaccharide, that we know enough to allow any useful discussion of origins.

Following any localised bacterial or virus infection, or any local injection of inactivated bacterial or virus cultures as a vaccine, antibody production is mainly a function of the lymph nodes draining the area. The evidence for this conclusion available in 1940 is fully reviewed by Burnet (I94I). Since then two groups of American workers have made important contributions in support of the thesis. Ehrich and his colleagues at Philadelphia (Ehrich and Harris, I942; Harris et al., I945; Ehrich et al., I946 ; Harris and Ehrich, I946) have studied the response in rabbits to antigens injected into the hind foot, with particular reference to the part played by the popliteal lymph node. Their experiments justify the conclusion that a large proportion of the antibody that eventually appears in the blood is produced in the lymph node which it leaves in the substance of lymphocytes, such as can be collected in the efferent lymph channel. When the vaccine was emulsified in paraffin oil the antibody response was enhanced, and concomitantly there was a marked accumulation of monocytic macrophage cells around the site of injection. These showed no excess of antibody, and again the evidence pointed to antibody production in the lymph node as being of major importance. 
The second group of workers, Dougherty, White and colleagues at New Haven (Dougherty and White, 1945; Chase, White, and Dougherty, I946), have approached the problem as physiologists interested in endocrine reactions. Their thesis is that lymphocytes are essentially storehouses of certain substances which are discharged into lymph and blood streams when needed. The discharge is accomplished by budding or dissolution of the cytoplasm with associated nuclear degeneration. The stimulus to discharge is the existence in the circulation of an effective concentration of adrenal cortical hormone. Experimentally the stimulus can be provoked by subcutaneous injection of either adrenal cortical extracts or the adrenotrophic hormone of the pituitary. Dougherty and White have shown that a protein of $\gamma$ globulin type can be obtained from lymphocytes, that there is marked disappearance of lymphocytes an hour or two after injection of appropriate hormones, and that this is associated with an increase in $\beta$ and $\gamma$ globulin content of the serum and, in appropriately immunised animals, with an increase in circulating antibody titre.

The two sets of findings are mutually consistent and in agreement with the findings of earlier workers. Any theory of antibody production must therefore be able to account for the special characteristics of this process taking place in the lymph nodes draining the area in which antigen was deposited.

There are three major histological characteristics of a lymph node which are relevant to the present discussion.

(I) The multiple afferent lymph vessels discharge into the cortical sinuses which are lined by numerous macrophages appropriately situated to take up micro-organisms or other foreign material reaching the node. As shown by Drinker, Field, and Ward (1934) the lymph node is a very effective bacterial filter.

(2) Dense nodules with (usually) germinal centres are distributed through the cortex of the node. These appear to represent the chief sites of lymphocyte production. The centres are filled with paler staining medium and large lymphocytes, reticular cells and macrophages. At the periphery there are densely packed small lymphocytes. Other accumulations of lymphocytes form the medullary cords, and from both sources small lymphocytes pass to the sinuses and leave the node by the efferent vessels emerging at the hilum.

(3) Phases of development and depletion of nodules occur and are presumably associated with the pituitary-adrenal endocrine mechanism described by Dougherty and White. In the phase of depletion there is evidence of marked destruction of lymphocytes.

The basic facts on which the interpretation of antibody production in lymph nodes must be based are (i) the phagocytosis of particulate antigenic material by macrophages which line the sinus spaces, (ii) the presence of antibody in (small) lymphocytes emerging from the node, and (iii) the fact that small lymphocytes are being constantly produced 
and destroyed. Any theory of antibody production which postulates the continuing presence in the antibody-producing cells of a template of antigen (or antigenic determinant) against which the antibody globulin is synthesised, must find an insuperable difficulty in the characteristically short life of the lymphocyte and the macrophage. The intense reactivity of a lymph node to toxic and hormonal influence with rapid multiplication and apparently almost catastrophic destruction of cells, provides no reasonable place for cells which can hold antigen and for weeks or months go on producing globulin molecules moulded on its specific pattern.

We would stress again that this discussion of the part played by lymphocytes in antibody production is based only on the response to parenteral injection or invasion of particulate antigens like foreign red cells and bacteria. It may be and probably is quite inapplicable to the production of antitoxins or to the development of various types of sensitisation.

\section{(c) The biological basis of immunological response}

The system of mesenchymal cells concerned with the production of antibody has many functions in the body, but in broad terms these functions can be reduced to three : ( I) the disposal of effete body cells and constituents, (2) phagocytosis and destruction of invading microorganisms, and (3) the production and perhaps transportation of antibody. These functions we may now consider.

(I) The best known type of expendable cell in the hody is the red blood cell. It is usually estimated that the maximum life of a red cell in the human circulation is about 120 days, $5^{\circ} \mathrm{ml}$. of cells being replaced daily. Effete cells are removed predominantly by macrophage cells in the splenic pulp. Lymphocytes as has been mentioned have much shorter average life, but their fate is more obscure. According to the theory of Dougherty and White (1945), under the stimulus of an increased circulating concentration of adrenal cortical hormones, lymphocytes liberate $\gamma$-globulin by shedding cytoplasm. The degenerating nuclei in lymph nodes are largely phagocytosed by macrophages, and it is reasonable to hold that this is also the fate of lymphocytes which have outlived their function in other parts of the body. In the repair of traumatised tissues damaged material of all types is normally dealt with by histiocytic cells of the macrophage type.

(2) The primary response to acute invasion by pathogenic micro-organisms is predominantly by polymorphonuclear leucocytes. Macrophage activity is more obvious with subacute or chronic infections, but even with acute infections the macrophage is concerned both with direct phagocytosis of micro-organisms and with the final disposal of leucocytes which have been damaged by taking up particulate or soluble bacterial material. The nature of the process of inflammation, destruction of pathogenic micro-organisms and 
repair is highly complex and varies considerably from one type of infection to another. Irrespective of complications, however, it appears to be generally accepted that the final fate of the substance of micro-organisms successfully resisted, as of the substance of damaged body cells, is reduction to its proximate constituents within macrophage cells and subsequent passage of these via the blood plasma to the general metabolic activities of the body.

(3) Looked at from the point of view of an adaptive mechanism, antibody production is a means to favour survival $(a)$ by providing a more efficient means of countering the later stages of the microorganismal infection that invoked the response, and $(b)$ to ensure that a future attack by the same micro-organism can be resisted effectively from the moment that infection is initiated. Again, the process is complicated and variable, but there can be no doubt about its importance as a factor of survival in an environment replete with potential pathogens. Nor is there any evidence that immunological reactivity has been evolved to favour survival by any other function than this provision of more effective means of dealing with microbic invasion. Most of the other circumstances by which immunological phenomena are invoked are grossly artificial, blood transfusions, intravenous or subcutaneous injections, skin grafting and so onand the resulting phenomena must be interpreted as the automatic responses of a mechanism "designed" for one purpose to an effective but "unreasonable" stimulus to which no biologically appropriate reaction is possible.

There are two current hypotheses as to how typical antibody is produced in mammals. The first, usually known as the HaurowitzMudd hypothesis, has been elaborated in detail by Pauling (1940) and is accepted by the majority of authors as essentially correct. It assumes that antibody is $\gamma$-globulin that has been spatially patterned at certain points-at the two ends of a bipolar molecule according to Pauling-by its synthesis in contact with the antigen molecule which acts as a template. The theory therefore demands that antibody is produced only so long as the essential antigenic determinants remain present in the antibody-producing cells. This has never been directly demonstrated, and for reasons given in detail in a previous discussion (Burnet, 1941) and summarised in previous sections of this paper, we consider that the weight of evidence is strongly against the persistence of antigen for the very long periods over which circulating antibody may be present.

The second hypothesis due to Burnet (194I) is that antibody production must be regarded as in many ways equivalent to the development of an adaptive enzyme process. On this view immunological phenomena derive essentially from the intrusion of a foreign pattern into that nest of uniquely patterned and mutually tolerant enzymes, the living substance of the cell. From practically every type of actively metabolising cell there can be extracted enzymes 
capable of breaking down each of the major types of substance, protein phospholipid and polysaccharide, characteristic of living matter. Within the living functioning cell their mutual destructiveness is curbed by some means which we cannot particularise, but which must be related in some way to their respective molecular patterns and to their spatial relationship to one another. Omitting for the time being the problem of the disposal of damaged cells or cell fragments of the body's own pattern, we assume that when an alien molecule or particle finds itself in such an environment it is somehow recognised as "not-self" and is subject to destruction by appropriate enzyme systems.

Adaptive enzyme systems are well known in bacteria and yeasts, and in one instance direct evidence has been obtained that an adaptive enzyme system once established can replicate itself indefinitely (provided the substrate is continuously present) independently of any nuclear genetic control (Spiegelman, Lindegren, and Lindegren, 1945).* Such an ability of cytoplasmic entities to replicate themselves in accordance with appropriate internal environmental stimuli is now being explicitly or tacitly accepted in a considerable range of biological phenomena, e.g. Billingham and Medawar's (r947 $a$ and $b$ ) work on the transfer of pigmentation in guinea-pig skin and that of Postgate and Hinshelwood (I946) on adaptive enzyme processes in Esch. coli mutabile. It is in line with the view developed particularly by Beadle (r945) but foreshadowed by Haldane (1942) and Wright (194I) that each gene controls a particular enzymic reaction and that in the last analysis the population of enzyme molecules concerned may represent the "descendants," by a process of replication or partial replication, of the gene itself. This view may be an unjustifiably wide extension of the conditions observed in regard to biochemical mutations in Neurospora, but it seems highly likely to be applicable to such situations as those concerned with antibody production.

The essentials of our hypothesis can be stated as follows. For reasons to be discussed in the next section, the enzyme systems concerned in the breakdown of antigenic particles or molecules require a certain degree of adaptive modification to function effectively against the foreign molecular pattern. Once this adaptation has occurred it is retained, persisting with replication of the enzyme system concerned. Possibly, as an immediate sequel to adaption and certainly after a recurrence of the same antigenic stimulus, replication of the system is greatly increased. If the cells concerned multiply or are converted into other types the modified enzyme systems are transmitted to their descendants. The appearance of antibody in the body fluids is to be regarded as a liberation, whether

* More recently Lindegren and Lindegren (1946) reported that they had been unable to repeat the experiments upon which the self-duplicating enzyme hypothesis was based. Repetition of experiments involving rare mutations is often very difficult, and final appraisal of the situation in yeasts must await further investigations. 
by cytoplasmic dissolution or otherwise, of partial replicas retaining the adsorptive pattern, but not necessarily the disintegrating capacity of thie modified enzyme systems.

The behaviour of one specialised type of immunological response, the development of tuberculin hypersensitiveness in infected animals strongly suggests that a type of antibody exists which can be transferred to other cells and confer on them the capacity of producing more antibody. If this is fully substantiated the possibility must be retained that complete replicas of the postulated enzyme systems can be transferred to other cells than those in which they were developed. We would suggest as one interpretation of the part played by the lymphocyte that there may be a transference of antibody-producing capacity from macrophages to the lymphocytes, which are always adjacent in the major sites of antibody production.

This general picture of antibody production is admittedly speculative, but we claim that it provides a reasonable interpretation of all the known characteristics of antibody production, including those which, in our view, render the Haurowitz-Mudd-Pauling theory untenable. Further, it is a view which seems to "fit" far better into the modern picture of intracellular processes that is being developed by biochemists and geneticists than the older theory.

The implications of the hypothesis for the genetic aspects of immunology are considered in the next section.

\section{GENE-ANTIGEN RELATIONSHIPS}

In practically every example that has been adequately studied, each antigenic pattern that is characteristic of the cells of some individuals and not others within a species, is inherited as if its character were controlled by a single gene. This has led to the suggestion, supported by Haldane (1 942), Sturtevant (I 944) and others, that the molecular pattern responsible for antigenic specificity might be traced back to the gene itself, and that in the last analysis the "code" by which phenotypic characters are represented in the chromosomal mechanism is equivalent in some way to the antigenic determinants which confer specific serological differences, e.g. between two of the artificial azoproteins of Landsteiner.

We feel that this may be an unduly sweeping generalisation. So far as the characters used in such studies of genetic material as we have described in earlier sections are concerned, a considerably simpler conception seems adequate.

The problem of antigenic individuality is most pressing in the field of reactions within the same species as exemplified by the production of red cell agglutinins and "blocking antibodies," or the intolerance of skin grafts from donors not isogenic with the recipient. At first glance there is a suggestion that almost every significant macro-molecule in the body may have an individuality that marks 
it off from similar macro-molecules in other individuals. But in fact there is good evidence that between any two individuals of a species common molecular patterns are much more frequent than antigenetically dissimilar ones. There are strains of mouse carcinoma for instance which can be readily transferred from one mouse to another in heterogeneous stocks without provoking regression, and the practicability of corneal transplantation in man would indicate a low grade only of specificity in the tissues concerned.

All that the available data make it necessary to postulate is that a well-defined mechanism has been evolved to allow a differentiation of the response of macrophage and similar cells to damaged or effete body constituents on the one hand, and to foreign organic matter (always micro-organismal under natural conditions) on the other. It is essential for obvious reasons that the first should not provoke the antibody response appropriate to the second.

It is therefore necessary to endow each scavenging or antibodyproducing cell with a capacity to " recognise" as foreign any potential antigenic determinants which are not represented in the body cells that it is liable to have to deal with under physiological or emergency conditions. Some qualification to this statement will probably be necessary to account for the special characteristics of the central nervous system and the chambers of the eye. Both situations are morphologically and physiologically shielded from concern with significant, i.e. non-fatal, emergencies, and their tolerance of implanted foreign tissues is probably in some way related to this characteristic.

Confining ourselves to the scavenging cells of the non-nervous tissues, unless we are prepared to admit an extraordinarily complex "code" by which such recognition of foreign structure is made, we are driven to the conclusion that all body cells carry some or all of a relatively small number of marker components whose specific character is determined by a correspondingly small number of genes. To account for the existence of individual differences, we must probably postulate a rather high mutation rate in these genes. The markers in question are not uniformly distributed to each type of cell. Medawar (1946b) has shown for instance that red cells from a donor animal will not "immunise" the recipient, so as to produce an accelerated response against a skin graft from the same donor, but that a leucocyte suspension will do so. This would indicate that there are different "markers" in red cells from those in leucocytes.

On this view there is within each phagocytic cell of the reticuloendothelial system a mechanism tuned to respond to any " self-marker" in material which it takes into its cytoplasm, by a non-immunological destructive process.

If organic material which contains none of the molecular patterns characteristic of the self-markers enters the cell, the latter responds by the development of the adaptive mechanism we have described, so initiating antibody production. In the embryonic animal, and 
probably in the cells associated with the central nervous system, this mechanism appears to be absent or modified.

It seems likely that antibody production is most effective when substances are present in the ingested foreign material, which are of the same general type as one of the self-markers but have a sharply distinct pattern. The mucopolysaccharide-protein complex carrying the $\mathrm{ABO}$ blood group, and also present in a wide variety of mucussecreting cells, is almost certainly one such marker. It is well known that the somewhat similar polysaccharide complexes present on the surface of most bacteria are particularly potent antigens.

This hypothesis may be put somewhat differently. Within the potential antibody-producing cells there are enzymic groups adapted genetically to "fit" a sufficient number of marker constituents to allow differentiation of " self" from " foreign" (i.e. normally invasive micro-organismal) organic material. When such a "fit" occurs, normal disintegration processes go on without stimulation to immunological activity. An antigen is such in virtue of the fact that it corresponds in its general chemical character to one or other of the self-markers, but will only fit the corresponding enzyme when this is deformed to an appropriate adaptive configuration. It is this deformation which provides the stimulus for replication and antibody liberation.

On this view the most effective antigenic stimulus will be from an antigen of general type closely corresponding to a marker but sufficiently distinct to demand a considerable adaptive deformation of the enzyme. Poor antigens may be either too close in character to the marker or so distant that only under unusual conditions can any type of contact with one of the enzymes be made. Where the material presented is of wholly distinct chemical type, e.g. racemised protein, no antibody is produced.

The difference between the effectiveness of primary and secondary antigenic stimuli, for which no explanation seems to be available on the Haurowitz-Mudd theory, requires some discussion. The present theory would assume on general biological analogies that a gradual reversion of the modified enzyme systems toward the original marker configuration would occur. The modified system would, however, for a long period remain particularly suited to react with represented specific antigen and would, moreover, be present in greater numbers as a result of the primary antigenic stimulus. There is no evidence to decide whether a new deformation is necessary to stimulate replication and antibody liberation, or whether the adapted mechanism responds by such replication to fresh contact with antigen irrespective of whether deformation is or is not necessary. What appears to be certain is that prolonged re-stimulation does result in modification of the antibody produced, and by hypothesis, therefore, deformation of the originally modified enzyme.

The use of adjuvants such as paraffin oil emulsion to intensify 
the antigenic response to a poor antigen would on our present hypothesis depend on the existence of a prolonged uniform flow of antigen to the cells. A poor antigen will only rarely find an opportunity to make effective contact with the marker enzyme most nearly appropriate. But if as a result of a few effective contacts replication of such modified, or partially modified, enzymes occurs, antigen arriving later will find more and more opportunity of making effective contact leading eventually to active antibody production.

Reverting now to the significance of genetically determined antigenic differences between related vertebrates, our conclusion would be that most of the differences that it is practical to study concern marker substances. Since of all cells the red blood corpuscles are those most extensively destroyed by cells of potential antibodyproducing capacity, markers for the components of the red cells are specially abundant. This, plus the convenience of experimental studies on the cells, are probably the reasons for the effective attack on genetic problems that has been possible in this field.

\section{CONCLUSION}

It must have been evident from this review that despite a promising beginning it will be long before a balanced integration of the mutually relevant aspects of immunology and genetics will be possible. At the present time, for reasons of practical importance and technical convenience, comprehensive data are practically confined to red cell antigens of vertebrates with minor contributions from work on the transplantation of normal and malignant tissues.

As far as red cell antigens are concerned it appears to be a legitimate generalisation that immunological differences of a single group of antigens within a species correspond to the different allelomorphs of a single gene. Further it seems that, in some way analogous to the existence of the appropriate $a$ or $\beta$ agglutinins in human beings of different blood groups, the reticulo-endothelial cells of the vertebrates contain enzyme systems genetically "tuned" to the antigens of the body cells which it is their function eventually to destroy. This concept of "self-marker" groupings of expendable body cells as a necessity to allow immunological or non-immunological response as required, is the main novelty in the present review.

The general theory of antibody formation that we have adopted is not accepted by immunologists generally. This may be due either to the inadequacy of evidence for the theory or because active work in immunology during recent years has been predominantly from the biochemical or physical-chemical point of view. We hope, however, to have shown that at least some such approach is necessary if immunological phenomena are to be integrated into the developing pattern of general biology.

Finally, we would attempt a few suggestions as to fields from which 
valuable help toward the construction of a real science of immunogenetics might come :-

(i) The first is from a combined biochemical, genetic, and immunological study of some convenient bisexual micro-organism such as Neurospora. This would eliminate the complications inherent in the use of vertebrate cellular antigens.

(ii) Either in connection with such a study or with other material the possibility of recognising specific enzyme molecules by immunological means should be explored. An antiserum specific for an enzyme present in the parent stock but not in a genetically defined mutant might become a most potent weapon for the development of genetic theory.

(iii) A close study of the limitations of immunological response in the sheltered tissues of the mammal, especially to the central nervous system and the eye, would probably throw much light not only on the basis of immunity but on some important medical problems, e.g. the etiology of multiple sclerosis.

(iv) There are interesting possibilities from experiments now technically possible, in which tissues which have been removed and stored in the cold are returned to the same donor animal after it has been subjected to some type of immunising or sensitising manipulation.

(v) Lastly there are still opportunities to be exploited in the immunological study of human identical twins particularly in regard to the details of allergic sensitivity.

\section{SUMMARY}

I. An outline is given of the general techniques and concepts of immunology as applied to genetic problems.

2. Research in immuno-genetics has been dominated by the necessity for dealing with practical problems arising out of the clinical use of blood transfusion and for this and other reasons most work has been concerned with the antigens of red blood cells. A summarised account of the conclusions in regard to the red cell antigens of mammalian and avian species is given.

3. Another important field also with immediate surgical implications is concerned with the reaction to tissue transplants from other individuals of the same species. The reaction against such transplants is of immunological character.

4. Without established exception there appears to be a one gene-one antigen correspondence.

5. The use of immunological techniques in the study of genetic problems has up to the present merely provided another means of recognising differences between two individuals and of elucidating the mechanism of inheritance of such differences. It is the main object of this review to stress that immunological phenomena have an interest for the geneticist at a much deeper level. Antibody 
production and the other manifestations of acquired immunity and specific sensitisation represent the most clear-cut examples of induced alteration in the chemical mechanisms of the organism. An attempt is made to present a biological interpretation of these phenomena in the form of a restatement of an earlier discussion by Burnet (I94I) on the production of antibodies.

The main features of this interpretation are: (I) Antibody production is dependent on processes analogous to those concerned in the development of adaptive enzymes in bacteria ; (2) the intracellular unit (enzyme?) modified by effective contact with the antigen is capable of replication and probably of transfer to other cells; (3) circulating antibody molecules are regarded as partial replicas of the intracellular units; (4) the production of antibody is not dependent on the continuing presence of antigen in the body.

6. A consideration of the cells involved in dealing with foreign organic material and in the production of antibody shows that these are the same cells as are concerned with removing and destroying effete or damaged body cells. No antibody is produced against components of such cells except perhaps under rare pathological conditions. The hypothesis is presented that differentiation between foreign and "self" components by cells of the reticulo-endothelial system depends on the existence of certain "marker" components on all expendable body cells. The number of markers is probably small and their character determined by a correspondingly small number of genes. Only a limited range of biologically significant molecules are "good" antigens, and there is evidence which suggests that only substances whose general chemical structure resembles that of one of the "markers" readily produce antibody. The differences observed by immunological methods amongst red cells may all be due to marker components.

7. In the concluding section a number of suggestions are made as to directions in which experimental studies might be developed if the outlines of the theoretical picture of immunogenetics which we have presented are to be filled in.

\section{REFERENCES}

AMINOFF, D., MORGAN, w. T. J., AND WATKins, w. M. I946. Specific serological characters of the mucoids of hog gastric mucin. Nature 158,879 .

BeAdLe, G. W. I945. Biochemical genetics. Chem. Rev. 37, I5.

BILlingham, R. E., AND MEDAWAR, P. B. I947a. The "cytogenetics" of black and white guinea-pig skin. Nature 159, II5.

BILlingham, R. E., AND MedaWAR, P. B. 1947b. The role of dendritic cells in the infective colour transformation of guinea-pig skin. Nature 160, 62.

BItTNER, J. J. 1944. The transplantation of splenic tissue in mice. Pub. Health Rep. 51, 244.

BURNET, F. M. 1934. Antigenic differences between related bacterial strains : a criticism of the mosaic hypothesis. Brit. 7. exp. Path. 15, 354.

BURNET, r. M. I94I. The production of antibodies. Walter and Eliza Hall Inst. Monograph I. Melbourne : Macmillan. 
CHASE, M. W. I94I. Inheritance in guinea-pigs of the susceptibility to skin sensitisation with simple chemical compounds. 7. exp. Med. 73, 7II.

CHASE, J. H., WHITE, A., AND DOUGHERTY, T. F. 1946. The enhancement of circulating antibody concentration by adrenal cortical hormones. F. Immunol. 52, IoI.

COOMBS, R. A., MOURANT, A. E., AND RACE, R. R. 1945. A new test for the detection of weak and " incomplete" $\mathrm{Rh}$ agglutinins. Brit. F. exp. Path. 26, 255.

CUMLEY, R. W., AND IRWIN, M. R. 1942. Individual specificity of human serum. 7. Immunol. 46,63 .

CUMLEY, R. W., IRWIN, M. R., AND COLE, L. J. I943. Genetic control of species specific antigens of serum. 7. Immunol. 47, 35 .

DOUGHERTX, T. F., AND WHITE, A. 1945. Functional alterations in lymphoid tissue induced by adrenal cortical secretion. Amer. F. Anat. 77, 81.

DRINKER, C. K., FIELD, M. E., AND WARD, H. K. 1934. The filtering capacity of lymph nodes. F. $\exp$. Med. $59,393$.

EHRICH, W. E., AND HARRIS, T. N. 1942. The formation of antibodies in the popliteal lymph node of rabbits. 7 . exp. Med. 76, 335 .

EHRICH, W. E., HARRIS, T. N., AND MERTENS, E. 1946. The absence of antibody in the macrophages during maximum antibody formation. F. $\exp$. Med. 83,373 .

FERGUSON, L. C. 1941. Heritable antigens in the erythrocytes of cattle. $\mathcal{F}$. Immunol. $40,213$.

FERGUSON, L. C., STORMONT, C., AND IRWIN, M. R. I942. On additional antigens in the erythrocytes of cattle. F. Immunol. 44, 147.

GIBSON, T., AND MEDAWAR, P. B. 1943. The fate of skin homografts in man. F. Anat., London, 77, 299.

GREENE, H. S. N. I 941 I . Heterologous transplantation of mammalian tumors. I. The transfer of rabbit tumors to alien species. F. exp. Med. 73, 461.

GREENE, H. S. N. 1941 $b$. Heterologous transplantation of mammalian tumors.

II. The transfer of human tumors to alien species. F. $\exp$. Med. 73, 474.

GREENE, H. S. N., AND MURPHY, F. D. 1945. The heterologous transplantation of mouse and rat tumors. Cancer Res. 5, 269.

GORER, P. A. 1938. The antigenic basis of tumor transplantation. F. Path. and Bact. 47, 231.

GORER, P. A. 1942. The role of antibodies in immunity to transplanted leukemia in mice. 7 . Path. Bact. 54,51 .

haLdANE, J. B. S. 1942. New paths in genetics. London: Allen and Unwin.

hanhart, E., IN Berger, w., AND hansen, K. " Allergie." Leipzig: Thieme. 1940.

HARRIS, M. I943a. The compatibility of rat and mouse cells in mixed tissue cultures. Anat. Rec. $87,107$.

HARRIS, M. 1943b. The role of humoral antagonism in heteroplastic transplantation in mammals. 7. exp. Med. 93, 131 .

HARRIS, T. N., AND EHRICH, W. E. 1946. The fate of injected particulate antigens in relation to the formation of antibodies. F. exp. Med. 84, I 56 .

HARRIS, T. N., GRIMM, E., MERTENS, E., AND EHRICH, W. E. 1945. The role of the lymphocyte in antibody formation. 7. exp. Med. 8r, 73 .

HIRSZFELD, L. 1947. The transition forms of blood groups. F. Immunol. 55, 14I. HIRSZFELD, L., AND AMZEL, R. 1940. Etude sur les pléiades' isozériques' du sang. Ann. Inst. Pasteur 65, 25I, 386.

IRWIN, M. R. 1946. Antigens, antibodies and genes. Biol. Rev., 21, 93.

IRWIN, M. R., AND CUMLEY, R. W. 1943. Immunogenetic studies of species relationships. The American Naturalist 77, 211 .

IRWIN, M. R., AND CUMLEY, R. W. 1945. Suggestive evidence for duplicate genes in a species hybrid in doves. Genetics 30,363 .

JACOBS, J. L., KELLEY, J. J., AND SOMMERS, s. c. I94 I. Hereditary predisposition to sensitization in guinea pigs. Proc. Soc. exp. Biol. N.Y. $48,639$.

LANDSTEINER, K. I92I. Ueber heterogenetisches antigen und hapten. XV. Mitteilung uber antigene. Biochem. Ztschr. 1rg, 294. 
LANDSTEINRB, x. 1928. Cell antigens and individual specificity. $\mathcal{F}$. Immunal. 15,589 .

LANDSTEINER, K. I946. The specificity of serological reactions. Cambridge, Mass. : Harvard University Press.

LANDSTEINER, K., AND WITT, D. H. I926. Observations on the human blood groups. Irregular reactions. Isoagglutinins in sera of group IV. The factor $\mathbf{A}^{\mathbf{1}}$. 7. Immunol. II, $22 \mathrm{I}$.

LANDSTEINER, K., AND VAN DER SGHEER, J. I936. On cross reactions of immune sera to azoproteins. 7. exp. Med. 63, 325 .

LEVINE, P., AND STETSON, R. E. 1939. An unusual case of intra-group agglutination. 7. Amer. med. Assoc. I13, 126.

LEWIS, P. A., AND LOOMTS, D. 1928. Allergic irritability. IV. The capacity of guinea pigs to produce antibodies as affected by inheritance and as related to familial resistance to tuberculosis. F. exp. Med. $47,437$.

LiNDEGReN, c. G., AND LINDEGReN, G. 1946. The cytogene theory. Cold Spring Harbor Sympo ia. Quant. Biol. XI, II5.

LitTle, G. C., IN SNELl, G. D. The biology of the laboratory mouse. Philadelphia. I $94 \mathrm{I}$.

LOEB, L. 1945. The biological basis of individuality. Springfield : Charles C. Thomas. LOEB, L., AND WRIGHT, s. 1927. Transplantation and individuality differentials in inbred families of guineapigs. Amer. F. Path. 3, $25 \mathrm{I}$.

maximow, A. A., AND BLoom, w. 1942. Textbook of histology. $4^{\text {th }}$ ed. Philadelphia and London.

$M^{c}$ GrBboN, W. H. I944. Cellular antigens in species hybrids in ducks. Genetics $29,407$.

MEDAWAR, P. B. 1944. The behaviour and fate of skin autografts and skin homografts in rabbits. $\mathcal{F}$. Anat., London, 78,176 .

MEDAWAR, P. B. 1945. A second study of the behaviour and fate of skin homografts in rabbits. F. Anat., London, 79, 157.

MEDAWAR, P. B. I946a. Immunity to homologous grafted skin. I. The suppression of cell division in grafts transplanted to immunized animals. Brit. F. exp. Path. 27,9 .

MEDAWAR, P. B. 1946b. Immunity to homologous grafted skin. II. The relation between antigens of blood and skin. Brit. F. exp. Path. 27, I5.

MEDAWAR, P. B., AND McDONALD, D. J. 1947. (Personal communication from P. B. Medawar.)

MORGAN, w. T. J. I947. The human ABO blood group substances. Experientia III, 7.

MORGAN, W. T. J., AND WADDELl, M. B. R. 1945. A specific blood group O substance. Brit. F. exp. Path. $26,387$.

MORGAN, W. T. J., AND WATKINS, W. M. 1945. The examination of rabbit anti-A immune serum produced by means of an artificial A-antigen. Brit. F. $\exp$. Path. 26, 247.

OWEN, R. D. I945. Immunogenetic consequences of vascular a nastomoses between bovine twins. Science 102, 400.

OWEN, R. D., STORMONT, G., AND IRWIN, M. R. I947. An immunogenetic analysis of racial differences in dairy cattle. Genetics 32,64 .

PAULING, L. 1940. A theory of the structure and process of formation of antibodies. 7. Amer. chem. Soc. 62, 2643.

POSTGATE, J. R., AND HINSHELWOOD, G. N. $\quad$ r 946 . The adaptation of $B$. lactis aerogenes and $B$. coli mutabile and various carbohydrates. Trans. Farad. Soc. 42,45 .

RACE, R. R. 1944. An "incomplete" antibody in human serum. Nature 153, $77 \mathrm{I}$.

RACE, R. R. 1946. The Rh blood groups. Schweiz. Med. Wchnschr. 37-38, 92 I.

SNYDER, L. H. 1946. Medical genetics and public health. Bull. New York Acad. Med. 22, 566 . 
SPIEGELMAN, S., LiNDEGREN, c. C., AND LINDEGReN, G. I945. Maintenance and increase of a genetic character by a substrate cytoplasmic interaction in the absence of the specific gene. Proc. Nat. Acad. Sci. 3I, 95.

StURTEVANT, A. H. I 944 . Can specific mutations be induced by serological methods? Proc. Nat. Acad. Sci. W.S. $30,176$.

TATUM, E. L., AND LeDERBERG, J. 1947. Gene recombination in the bacterium Escherichia coli. 7. Bact. 53, 673 .

TODD, c. 1930. Cellular individuality in the higher animals, with special reference to the individuality of the red blood corpuscle. Proc. Roy. Soc. "B" ro6, 20.

TODD, C., AND WHITE, R. G. IgIO. On the hæmolytic immune isolysins of the ox and their relation to the question of individuality and blood relationship. 7., Hyg., Camb., Io, 185.

WHEELER, K. M., SAWIN, P. B., AND STUART, C. A. 1939a. Group specific agglutinins in rabbit serum for human cells. V. Inheritance of the A character. $\mathcal{F}$. Immunol. 36,349 .

WHEELER, K. M., SAWIN, P. B., AND STUART, C. A. I939b. Group-specific agglutinins in rabbit serums for human cells. VI. Immune specific M-agglutinins. $\mathcal{F}$. Immunol. 37, 159 .

WIENER, A. s. 1943. Blood groups and blood transfusion. Springfield : Charles C. Thomas.

WIENER, A. S., AND SONN-GORDON, E. B. 1947. Preparation of anti-Rh serum. Amer. 7. clin. Path. $17,67$.

WIENER, A. S., SONN, E. B., AND POLIVKA, H. R. 1946. Heredity of Rh blood types. V. Improved nomenclature; additional family studies with special reference to Hr. Proc. Soc. exp. Biol. N.Y. 6I, 382 .

WIENER, A. S., ZIEVE, I., AND FRIES, J. H. 1937. The inheritance of allergic disease. Ann. Eugenics 7, 141 .

Wright, s. 1941. The physiology of the gene. Physiol. Rev. 21, 487. 